DOI: 10.19085/journal.sijmd021204

\title{
Demographic Dividend: The Rich Source of Skilled People in India
}

\author{
Dr. Shivesh
}

Asst. Professor, M.B.A. Agri Business, RGSC, Banaras Hindu University, Varanasi, UP, India.

OScholedge International Journal of Management \& Development ISSN 2394-3378, Vol.02, Issue 12 (2015) pg31-36.

Published by: Scholedge R\&D Center [www.theSCHOLEDGE.org] [Email: sijmd@scholedge.org]

\section{ABSTRACT}

As compared to western economies where there is a burden of an ageing population, India has a unique 20-25 years window of opportunity called the "demographic dividend." The current focus of skill development has shifted to the learner and his/her needs and expectations from vocational education and training. To empower the working population, is it essential to start from the source, i.e., the learner. Our Country is having largest young population than any other country which acts as a power to make India a stronger and sustainable nation.

India is a rich source of Skilled peoples, the aim of the paper is to understand and comprehend the issues surrounding skill development in the field of healthcare the paper also shows some issues which shows that from long time India is rich in skills.

Keywords: Demographic dividend, Skill Development in India, Human Capital

\section{Introduction}

While comparing with western economies where there is a burden of an ageing population, India has a unique 20-25 years window of opportunity called the "demographic dividend." This "demographic dividend" means that as compared to other large developing and developed countries, India has a higher proportion of working age population vis-à-vis its entire population." The result is low dependency ratio, which can provide a comparative cost advantage and competitiveness to the economy. The following charts provide a glimpse of the demographic dividend that India would be able to achieve. Further, it is expected that the ageing economy phenomenon will globally create a skilled manpower shortage of about 56.7 million by 2020. With the rising trend of outsourcing work globally, India has the opportunity to become a global reservoir of skilled manpower, accounting for $28 \%$ of the graduate talent pool among 28 of the world's lowest-cost economies. Among all the 
countries, India enjoys a unique advantage not only to fulfil its internal demand of skill manpower, but also cater to the labour shortage in other countries. The government is taking proactive steps to fill the existing skill gap in order to leverage its position as a supplier of skilled manpower to the world.

Projected growth and sector demand India is expected to grow at a rate of $8 \%$, on an average, in the next 10 years5. More than 700 million Indians are estimated to be of working age by 2022. Out of these, more than 500 million require some kind of vocational or skill development training6. Twelfth Five Year Plan: The country has set a tough challenge in the field of vocational education and training in its approach paper in the Twelfth Five Year Plan. It aims to increase the percentage of workforce with formal skills to $25 \% 7$ at the end of the plan. It is estimated that 50-70 million jobs will be created in India over the next five years and about $75 \%-90 \%$ of these additional employment avenues will require some vocational training. The following table presents the projected employment in the various sectors of economy for diverse growth scenarios till 2017.

\section{Government focus on skill development}

Skill development is one of the priority agendas of the government for the Twelfth Five Year Plan. The government plans to set up sector skill councils to prepare standards required for training programs. The industries are also proactively taking steps to partner with the government and reduce the skill gap.

\section{Financial support}

Budget proposals for 2016-17 in Parliament, "education, skills and job creation" to make India a knowledge-based and productive society as one of the 'nine pillars' that would transform the country.

Government has allocated a sum of Rs 1804 crore for setting up 1,500 multi-skill training institutes in the country and scaling up Pradhan Mantri Kaushal Vikas Yojna.

Government has decided to set up National Board for Skill Development Certification in partnership with the industry and academia. We propose to further scale up Pradhan Mantri Kaushal Vikas Yojna to skill one crore youth over the next three years.

\section{Traditional skill in Health Care in India}

India is a mine of one of the best skilled healthcare practitioners and not only in medicines but also in surgery which will be discussed.

Indian traditional medicine is considered as Ayurveda, one of the oldest and popular book known as Susruta Samhita defines health as given below: 
Susruta defines a healthy individual as

samadosha: samagnischasamadhatumalakriya:

prasannatmaindriyamana: svasthaitiabhidheeyate

$$
\text { (ch.15/ verse 41) }
$$

In essence, "a healthy person is one whose dosha, dhatu(structural entities) and metabolic end products are in equilibrium. Further, there must also be clarity in consciousness, senses and mind for a healthy state."

Some greatest and noble practitioners in Health Care are from India some are like Sushruta, Charaka. Sustruta is considered as pioneer and father of Surgery and he study medicine and surgery in Varanasi from king of city in 600 BCE. Charaka is considered as father of medicine, the term Charaka is a label said to apply to "wandering scholars" or "wandering physicians". According to Charaka's translations, health and disease are not predetermined and life may be prolonged by human effort and attention to lifestyle. As per Indian heritage and Ayurvedic system, prevention of all types of diseases have a more prominent place than treatment, including restructuring of lifestyle to align with the course of nature and four seasons, which will guarantee complete wellness. Charaka is generally considered as the first physician to present the concept of digestion, metabolism and immunity. He is the first person who explains that heart is main part of body and connected to entire body from 13 channels.

\section{A spotlight on key issues}

The Skill gap exists in the following areas:-

- Inadequate ability to adhere to standard hospital procedures, inadequate ability to think differently and the tendency to have a limited thought process.

- Inadequate communications skills especially when dealing with international clientele.

- Inadequate exposure to technology and thus inadequate hands-on experience of operating machines as most of the learning happens on the job.

- Inadequate knowledge of basic languages needed to converse with multiple set of patients as many nurses are trained in South India and they are unable to converse in English and Hindi / in the local language. 
- There is also an envisaged shortage of around 2.36 lakh medical technologists, 1.98 lakh surgical and intervention technology-related health professionals, 1.28 lakh ophthalmology-related workers, 61,670 medical laboratory professionals and over 19,217 radiography and imaging experts in India according to the health ministry estimates.

- The industry and the National Assessment and Accreditation Council (NAAC) have gone on record to state that barely $10 \%$ of the 30 lakh students, who pass with these degrees every year, are considered employable in today's competitive world. This is true in the healthcare sector as well.

- A critical skill is one that, if not present, results in a task not being completed satisfactorily, if at all and the lack of a critical skill causes problems, but the possession of it allows work to continue.

- In India, the skills gap is threatening the country's sustained economic growth and limiting opportunities for struggling workers. This is not the only challenge we face. Inadequate aggregate demand is the primary driver of unemployment and trends such as declining wages for entry-level jobs contribute to income inequality. We need solutions that address all these issues. In India "National Skill Development Coordination Board" is the designated agency under NEETI AAYOG which is responsible for skill development.

\section{The Real Challenge for Employers}

While millions of people are looking for jobs, employers report that they are struggling to find skilled workers. As a country, we need to address the question of whether we can afford ... to write off nearly half of our younger-adult population as not having the skills needed to effectively engage as full and active participants in their own future and that of our nation.

Around the world, employers, educators, policymakers, training organizations, and others have recognized the critical importance of tackling the skills gap. Helping people develop the skills they need to compete for today's jobs can transform lives and strengthen economies.

While we clearly foresee skill gap being a major contributor in hampering the efficiency of overall system, we need to think on the following proposed solutions to reduce the size of the problem immediately.

a) Expand a sector-focused workforce development system. A sector-focused workforce development system is responsive to the needs of the country's highdemand sectors. The system must rely on multiple sources of labor market 
information and continuous engagement with employers in order to be responsive to sectors' evolving expectations and priorities.

b) Create additional career pathways aligned with labor demand in healthcare.

In order to be effective, the education and training provided in a career pathways system must be aligned with local labor market demand and provide job seekers with the employment skills and middle-skill credentials this sector require.

c) Implement policies that incentivize a systemic approach to sector-focused career pathway development.

Leverage local, state, and federal policies that support sector-based career pathways and allocate resources to programs that best prepare workers for high-demand, middle-skill jobs with career mobility.

d) Develop funding strategies that can sustain and scale a system of career pathways and expand the sector-focused approach to workforce development. Public Investments and private philanthropy should align with the career pathways approach to ensure that the ecosystem of training and education providers can equip job seekers with the skills and credentials that employers require for high demand, middle-skill jobs.

\section{Conclusion:}

As we discussed in the paper, there is huge gap in the current position of skilled workforce and required workforce there are certain reasons which play vital role in this aspect as our people are neglecting traditional knowledge such as giving preference to Allopathic medicine more as compare to Ayurveda which is used in large previously we have to adopt certain measure to preserve our traditional skill in healthcare and to understand and grasp the innovative and new knowledge base related to healthcare.

\section{References:}

1. Government of India (2004). India Vision 2020. New Delhi: Planning Commission.

2. Government of India (2014). Demand Responsive Vocational Training. New Delhi: Directorate General of Employment and Training, Ministry of Labour \& Employment.

3. Government of India (2011). Second Annual Report to the People on Employment. New Delhi: Ministry of Labour \& Employment. 
4. The World Bank and International Labour Organisation (ILO) (2013). Possible Futures for the Indian Apprenticeship System, Options Paper for India.

5. National Skill Development Corporation. Human Resource and Skill Requirements in the Capital Goods Sector (2012-17, 2017-22).

6. Government of India- Ministry of Skill Development \& Entrepreneurship, National Skill Development Corporation and KPMG. Human Resource and Skill Requirements in the Food Processing Sector (2013-17, 2017-22).

7. Government of India (2015). Draft National Policy for Skill Development and Entrepreneurship 2015. New Delhi: Ministry of Skill Development \& Entrepreneurship

8. Advisor to the Prime Minister, National Council on Skill Development. E Skill Development

9. National Skill Development Agency (NSDA) and the National Skill Development Corporation (NSDC) (2014). Youth Empowerment through Skill Development.

10. Mehrotra, Santosh, Ankita Gandhi and Bimal K. Sahoo (2013): "Estimating the Skill Gap on a Realistic Basis for 2022", Institute of Applied Manpower Research, Planning Commission, Government of India

11. FICCI-KPMG (2012).Skilling India- a look back at the progress, challenges and the way forward.

12. FICCI-Ernst \& Young (2012). Knowledge Paper on Skill Development in India-Learner First.

13. Government of India, FICCI, BIBB (Germany), Federal Ministry of Education and ResearchiMove (Germany) and National Skill Development Corporation (India). Forging India Germany Partnerships in Skills Development. New Delhi: Ministry of Labour \& Employment, Ministry of External Affairs.

14. Government of India (2013-14). Education, Skill Development and Labour Force, Volume-3. New Delhi: Labour Bureau, Ministry of Labour \& Employment. 